ISSN: 2576-9200

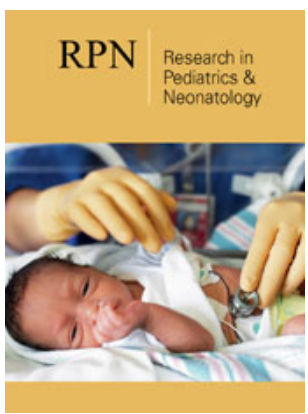

*Corresponding author: Joanna Jasińska, Warsaw Medical University named Tadeusz Kozluk, Warsaw, Poland

Submission: 眥 August 11, 2020

Published: 㘹September 30, 2020

Volume 4 - Issue 5

How to cite this article: Grażyna Bączek, Alicja Misztal, Anna Kajdy, Dorota Sys, Barbara Baranowska, Joanna Jasińska. Childbirth Yesterday and Today: A Comparative Analysis of Women's Experiences and Feelings Through the Ages to The Present. 4(5). RPN. 000600. 2020. DOI: $10.31031 / R P N .2020 .04 .000600$

Copyright $(\subset$ Joanna Jasińska. This article is distributed under the terms of the Creative Commons Attribution 4.0 International License, which permits unrestricted use and redistribution provided that the original author and source are credited.

\title{
Childbirth Yesterday and Today: A Comparative Analysis of Women's Experiences and Feelings Through the Ages to The Present
}

\author{
Grażyna Bączek ${ }^{1}$, Alicja Misztal $^{2}$, Anna Kajdy ${ }^{3}$, Dorota Sys ${ }^{4}$, Barbara \\ Baranowska $^{5}$ and Joanna Jasińska ${ }^{6 *}$ \\ ${ }^{1}$ Medical University of Warsaw, Department of Gynecologic and Obstetrical Didactics,Warsaw, \\ Poland \\ ${ }^{2}$ Department of Gynecologic and Obstetrical Didactics, Medical University of Warsaw, Poland \\ ${ }^{3}$ St. Sophia's Specialist Hospital, Warsaw, Poland \\ ${ }^{4}$ Department of Reproductive Health, Centre of Postgraduate Medical Education, Warsaw, \\ Poland \\ ${ }^{5}$ Department of Midwifery, Centre of Postgraduate Medical Education, Warsaw,Poland \\ ${ }^{6}$ Warsaw Medical University named Tadeusz Kozluk,Warsaw, Poland
}

\begin{abstract}
Introduction: Perinatal care has undergone many changes over time. Therefore, women's feelings andexperiences will differ depending on the perinatal care provided at the time of childbirth. Time of childbirth and the perinatal care received are the main determinants in this process. However, one thing remains unchanged over time. Childbirth is considered one of the most notable events in the life of every woman. The aim of the study was a comparative analysis of experiences and feelings shared by females giving birth in the past and the present in Poland.
\end{abstract}

Material and methods: A questionnaire was designed specifically for this research project. It was a set of multiple choice (single answer) questions concerning childbirth conditions and perinatal care. Results were analyzed with a chi square test. Data was collected in 2016 in Poland. The questionnaire was distributed both in paper and electronic form.

Results: The study group comprised of 671 females divided into three groups: childbirth before 2000, between 2001-2012, and after 2013. This time frame was associated with significant changes in perinatal care in Poland over the years. Changes in the delivery rooms have raised the comfort of childbirth, but progression of obstetrics resulted in greater medicalization of childbirth.

Conclusions: Refinement of qualified assistance in labour, oriented on individual needs contributes to improvement of perinatal care and perhaps compensates for other inconveniences. It is necessary to put achievements of modern medicine-in order to ensure maternal safety during childbirth but not to disrupt its natural process.

Keywords: Childbirth;Perinatal care; Midwife; Childbirth experiences

\section{Introduction}

Perinatal care has undergone many changes over time. Therefore, women's feelings and experiences will differ depending on the perinatal care provided the time of childbirth. Time of childbirth and the perinatal care received are the main determinants in this process. However, one thing remains unchanged over time. Childbirth is considered one of the most notable events in the life of every woman. Today, it is hard to envision that only 100 years ago, females in Poland would give birth at home with the assistance of uneducated women who oftentimes utilized primitive obstetric practices based on folk medicine. Childbirth was considered a physiological condition, although much of the phenomena was not understood. The development of obstetrics knowledge and techniques has contributed to the reduction of perinatal mortality but has led to the medicalization of childbirth. It was then confined to the extraction of the fetus which was very often accompanied by many medical interventions. Currently, the biopsychosocial aspects of childbirth have been acknowledged. As a result, both the mother and her baby are the most important subjects at time of labor and delivery, 
and their safety can be guaranteed by available equipment. In the 1990s, many changes in obstetrics were introduced in Poland to improve perinatal care.

\section{Material and Methods}

The study included 671 females that gave birth in Poland. A detailed list of selected socio-economic factors is presented in Table 1. A survey questionnaire was developed for the purpose of this research project. The study was carried out anonymously. All respondents provided written informed consent before enrollment. It was distributed in both paper and electronic forms. The research subject, which is part of a large project, was approved by the Bioethics Committee of the Medical University of Warsaw No. AKBE/161/17 (date: September 5, 2017). The survey contained multiple choice (single answer) questions and concerned childbirth conditions and perinatal care provided by medical personnel. The Likert scale was used to examine respondents' feelings. All participants were divided into three groups. The inclusion criterion for individual groups was the date of delivery. A detailed rationale for this division is given in Table 2. Differences between the variables were compared using the chi square test. The significance level was at $\mathrm{p}<0.05$. The calculations were made using the IBM SPSS Statistics 22 program.

Table 1: Socioeconomic factors of respondents.

\begin{tabular}{|c|c|c|}
\hline Variable & $\mathbf{N}$ & $\%$ \\
\hline \multicolumn{3}{|c|}{ Education } \\
\hline Primary school & 21 & $3.10 \%$ \\
\hline Middle school & 3 & $0.40 \%$ \\
\hline Vocational school & 68 & $10.10 \%$ \\
\hline Secondary school & 182 & $27.10 \%$ \\
\hline University & 397 & $59.20 \%$ \\
\hline \multicolumn{3}{|c|}{ Marital status } \\
\hline Single & 83 & $12.40 \%$ \\
\hline Married & 541 & $80.60 \%$ \\
\hline Divorced & 36 & $5.40 \%$ \\
\hline Widow & 11 & $1.60 \%$ \\
\hline \multicolumn{3}{|c|}{ Place of residence } \\
\hline Village & 113 & $16.80 \%$ \\
\hline $\begin{array}{l}\text { City with less than } 50,000 \\
\text { residents }\end{array}$ & 94 & $14 \%$ \\
\hline $\begin{array}{c}\text { City with } 50,000-250,000 \\
\text { residents }\end{array}$ & 119 & $17.70 \%$ \\
\hline $\begin{array}{c}\text { City with } 250,000-500,000 \\
\text { residents }\end{array}$ & 76 & $11.30 \%$ \\
\hline $\begin{array}{l}\text { City with over } 500,000 \\
\text { residents }\end{array}$ & 269 & $40.10 \%$ \\
\hline
\end{tabular}

Table 2: The process of changes in Polish obstetrics in the context of the research project analyzing perinatal experiences of women in Poland.

\begin{tabular}{|c|c|c|c|c|}
\hline \multirow{2}{*}{$\begin{array}{l}\text { Time } \\
\text { Frame }\end{array}$} & \multirow{2}{*}{$\begin{array}{c}\text { Important Processes and } \\
\text { Phenomena }\end{array}$} & \multicolumn{3}{|c|}{ Study Group } \\
\hline & & Group & $\mathbf{N}$ & $\%$ \\
\hline $\begin{array}{l}\text { Until } 2000 \\
\text { inclusive }\end{array}$ & $\begin{array}{c}\text {-1983-first childbirth with a } \\
\text { birth partner in Poland } \\
\text { · 1993-launch of a nationwide } \\
\text { program for the improvement of } \\
\text { perinatal care } \\
\text { · 1993-presentation delivered } \\
\text { by Sheila Kitzinger at the } \\
\text { Warsaw Congress entitled: The } \\
\text { Quality of Birth, the Quality of } \\
\text { Life, which initiated the Child- } \\
\text { birth with Dignity campaign } \\
\text { - 1994-publication of question- } \\
\text { naires Childbirth with Dignity } \\
\text { that allowed women to share } \\
\text { their birth experiences } \\
\text {. 1996-first water birth in } \\
\text { Poland } \\
\text { 1996-introduction of majors } \\
\text { in obstetrics by universities, } \\
\text { allowing midwives to obtain } \\
\text { higher education } \\
\text { 1996-implementation of the } \\
\text { Act on the Professions of Nurse } \\
\text { and Midwife } \\
\text { Since the events described } \\
\text { above took place at the close of } \\
\text { the 20th century, the year } 2000, \\
\text { being on the borderline with the } \\
\text { closing year for the first group } \\
\text { of respondents. }\end{array}$ & 1 & 148 & $22.00 \%$ \\
\hline $\begin{array}{l}2001- \\
2012\end{array}$ & $\begin{array}{l}\text { Memories shared by these } \\
\text { respondents were to show } \\
\text { how the progressive changes } \\
\text { observed in obstetrics were } \\
\text { reflected during childbirth. } \\
\text { The closing year for the second } \\
\text { group was } 2012 \text {. At that time, } \\
\text { new guidelines regarding peri- } \\
\text { natal care were introduced-the } \\
\text { Perinatal Care Standards spec- } \\
\text { ified in the Regulation of the } \\
\text { Ministry of Health of September } \\
20,2012 \text {. Since the survey ques- } \\
\text { tionnaire included only the year } \\
\text { of delivery, it was not possible } \\
\text { to distinguish births before and } \\
\text { after September } 20 \text {. Therefore, } \\
\text { all surveyed women who gave } \\
\text { birth in } 2012 \text { were included in } \\
\text { the second group. }\end{array}$ & 2 & 171 & $25.50 \%$ \\
\hline $\begin{array}{c}\text { Since } \\
2013 \\
\text { inclusive }\end{array}$ & $\begin{array}{l}\text { Answers provided by women } \\
\text { giving birth in this period were } \\
\text { to show childbirth nowadays } \\
\text { and whether perinatal care is } \\
\text { given according to the guide- } \\
\text { lines contained in the Perinatal } \\
\text { Care Standards. }\end{array}$ & 3 & 352 & $52.50 \%$ \\
\hline
\end{tabular}




\section{Results}

During the studied period childbirth facilities have gradually improved. Shared delivery rooms were replaced by single rooms (a decrease in the number of births in shared rooms by $28.8 \%$, and then by $40.5 \%$ versus the first group). Also, more and more women were allowed to drink, have a birth partner, use nonpharmacological methods for labor pain relief and take comfortable positions. The percentage of pre-labor routine procedures such as perineal shaving or enema administration has decreased over the years. In the last century, more than half of pregnant women underwent these procedures without prior informed consent. However, the vast majority of studied women $(65.5 \%, 73.3 \%$ and $62 \%, 79.3 \%)$ who gave birth between 2001 and 2016, have avoided these procedures. Progressive medicalization of childbirth was observed over the studied years. It was found that more than half of women from the first group had not been administered uterotonics, while in the two other groups, it was around $30 \%$. There was a noticeable

Table 3: Medical procedures performed in respondents. increase in the percentage of women who had benefited from pharmacological anesthesia during childbirth. Specifically, for the first group, it was only $5.4 \%$, for the second group 38\%, reaching almost half of respondents in the third group. Despite a decrease in the number of women with episiotomy performed without prior informed consent, it still remained at a high level (respectively: $60.1 \%, 40.9 \%$, up to $20.7 \%$ ). Table 3 . All respondents were asked about their childbirth-related memories as well as the level of satisfaction with perinatal care. Majority reported to have positive memories. Also, for the most part, they claimed that they had felt satisfied with the perinatal care received. Nonetheless, the level of satisfaction and positive memories has increased over time. Table 4. Table 5 presents the results concerning the place and methods of delivery. The vast majority of women gave birth in public hospitals (over $90 \%$ in each group). The frequency of C-sections was found to have increased over time. While in the first group this percentage was less than $5 \%$, in the remaining groups an upward trend was observed (14.6\% in the second group and $21.6 \%$ in the third group).

\begin{tabular}{|c|c|c|c|c|c|c|}
\hline \multicolumn{7}{|c|}{ Did you have an enema administered prior to your childbirth? } \\
\hline \multirow[b]{2}{*}{ Answers } & \multicolumn{2}{|c|}{$\begin{array}{c}\text { Group } 1 \\
\mathrm{~N}=148\end{array}$} & \multicolumn{2}{|c|}{$\begin{array}{c}\text { Group } 2 \\
\mathrm{~N}=171\end{array}$} & \multicolumn{2}{|c|}{$\begin{array}{c}\text { Group } 3 \\
\mathrm{~N}=352\end{array}$} \\
\hline & $\%$ & $\mathbf{N}$ & $\%$ & $\mathbf{N}$ & $\%$ & $\mathbf{N}$ \\
\hline Yes, after prior informed consent for this procedure. & $13.50 \%$ & 20 & $17.50 \%$ & 30 & $18.20 \%$ & 64 \\
\hline Yes, but without prior informed consent for this procedure. & $51.40 \%$ & 76 & $15.80 \%$ & 27 & $8.00 \%$ & 28 \\
\hline No & $25.70 \%$ & 38 & $65.50 \%$ & 112 & $73.30 \%$ & 258 \\
\hline I don't remember & $9.50 \%$ & 14 & $1.20 \%$ & 2 & $0.60 \%$ & 2 \\
\hline \multicolumn{7}{|c|}{$\chi^{2}(2)=175.876 ; p<0.001$} \\
\hline \multicolumn{7}{|c|}{ Did you have perineal shaving performed prior to your childbirth? } \\
\hline & \multicolumn{2}{|c|}{$\begin{array}{c}\text { Group } 1 \\
\mathrm{~N}=148\end{array}$} & \multicolumn{2}{|c|}{$\begin{array}{c}\text { Group } 2 \\
\mathrm{~N}=171\end{array}$} & \multicolumn{2}{|c|}{$\begin{array}{c}\text { Group } 3 \\
\mathrm{~N}=352\end{array}$} \\
\hline Answers & $\%$ & $\mathbf{N}$ & $\%$ & $\mathbf{N}$ & $\%$ & $\mathbf{N}$ \\
\hline Yes, after prior informed consent for this procedure. & $12.80 \%$ & 19 & $15.80 \%$ & 27 & $10.50 \%$ & 37 \\
\hline Yes, but without prior informed consent for this procedure. & $58.80 \%$ & 87 & $18.10 \%$ & 31 & $8.50 \%$ & 30 \\
\hline No & $22.30 \%$ & 33 & $62.00 \%$ & 106 & $79.30 \%$ & 279 \\
\hline I don't remember & $6.10 \%$ & 9 & $4.10 \%$ & 7 & $1.70 \%$ & 6 \\
\hline \multicolumn{7}{|c|}{$\chi^{2}(2)=184.391 ; p<0.001$} \\
\hline \multicolumn{7}{|c|}{ Were you allowed to use pharmacological anesthesia during your childbirth? } \\
\hline & \multicolumn{2}{|c|}{$\begin{array}{c}\text { Group } 1 \\
N=148\end{array}$} & \multicolumn{2}{|c|}{$\begin{array}{c}\text { Group } 2 \\
\mathbf{N}=171\end{array}$} & \multicolumn{2}{|c|}{$\begin{array}{c}\text { Group } 3 \\
\mathrm{~N}=352\end{array}$} \\
\hline Answers & $\%$ & $\mathbf{N}$ & $\%$ & $\mathbf{N}$ & $\%$ & $\mathbf{N}$ \\
\hline Yes & $5.40 \%$ & 8 & $38.00 \%$ & 65 & $48.90 \%$ & 172 \\
\hline No & $73.00 \%$ & 108 & $31.60 \%$ & 54 & $27.50 \%$ & 97 \\
\hline I don't remember & $11.50 \%$ & 17 & $14.60 \%$ & 25 & $6.00 \%$ & 21 \\
\hline Not applicable & $10.10 \%$ & 15 & $15.80 \%$ & 27 & $17.60 \%$ & 62 \\
\hline \multicolumn{7}{|c|}{$\chi^{2}(2)=126.484 ; p<0.001$} \\
\hline \multicolumn{7}{|c|}{ Did you have uterotonics administered during your childbirth? } \\
\hline & \multicolumn{2}{|c|}{$\begin{array}{c}\text { Group } 1 \\
N=148\end{array}$} & \multicolumn{2}{|c|}{$\begin{array}{c}\text { Group } 2 \\
\mathrm{~N}=171\end{array}$} & \multicolumn{2}{|c|}{$\begin{array}{c}\text { Group } 3 \\
\mathrm{~N}=352\end{array}$} \\
\hline
\end{tabular}




\begin{tabular}{|c|c|c|c|c|c|c|}
\hline Answers & $\%$ & $\mathbf{N}$ & $\%$ & $\mathbf{N}$ & $\%$ & $\mathbf{N}$ \\
\hline Yes, after prior informed consent for this procedure. & $5.40 \%$ & 8 & $23.40 \%$ & 40 & $31.00 \%$ & 109 \\
\hline Yes, but without prior informed consent for this procedure. & $27.00 \%$ & 40 & $25.70 \%$ & 44 & $23.90 \%$ & 84 \\
\hline No & $52.70 \%$ & 78 & $32.20 \%$ & 55 & $30.40 \%$ & 107 \\
\hline I don't remember & $10.10 \%$ & 15 & $5.30 \%$ & 9 & $4.00 \%$ & 14 \\
\hline Not applicable (Elective C-section) & $4.70 \%$ & 7 & $13.50 \%$ & 23 & $10.80 \%$ & 38 \\
\hline \multicolumn{7}{|c|}{$\chi^{2}(2)=58.194 ; p<0.001$} \\
\hline \multicolumn{7}{|c|}{ Did you have episiotomy performed during your childbirth? } \\
\hline & \multicolumn{2}{|c|}{$\begin{array}{c}\text { Group } 1 \\
\mathrm{~N}=148\end{array}$} & \multicolumn{2}{|c|}{$\begin{array}{c}\text { Group } 2 \\
\mathrm{~N}=171\end{array}$} & \multicolumn{2}{|c|}{$\begin{array}{c}\text { Group } 3 \\
\mathrm{~N}=352\end{array}$} \\
\hline Answers & $\%$ & $\mathbf{N}$ & $\%$ & $\mathbf{N}$ & $\%$ & $\mathbf{N}$ \\
\hline Yes, after prior informed consent for this procedure. & $3.40 \%$ & 5 & $16.40 \%$ & 28 & $19.30 \%$ & 68 \\
\hline Yes, but without prior informed consent for this procedure. & $60.10 \%$ & 89 & $40.90 \%$ & 70 & $20.70 \%$ & 73 \\
\hline I did not have episiotomy performed. & $25.00 \%$ & 37 & $20.50 \%$ & 35 & $33.80 \%$ & 119 \\
\hline I don't remember & $3.40 \%$ & 5 & $1.20 \%$ & 2 & $0.00 \%$ & 0 \\
\hline Not applicable (Elective C-section) & $8.10 \%$ & 12 & $21.10 \%$ & 36 & $26.10 \%$ & 92 \\
\hline \multicolumn{7}{|c|}{$\chi^{2}(2)=102.975 ; p<0.001$} \\
\hline \multicolumn{7}{|c|}{ Did you have amniotomy performed during your childbirth? } \\
\hline & \multicolumn{2}{|c|}{$\begin{array}{l}\text { Group } 1 \\
N=148\end{array}$} & \multicolumn{2}{|c|}{$\begin{array}{c}\text { Group } 2 \\
\mathrm{~N}=171\end{array}$} & \multicolumn{2}{|c|}{$\begin{array}{c}\text { Group } 3 \\
\mathrm{~N}=352\end{array}$} \\
\hline Answers & $\%$ & $\mathbf{N}$ & $\%$ & $\mathbf{N}$ & $\%$ & $\mathbf{N}$ \\
\hline Yes, after prior informed consent for this procedure. & $2.70 \%$ & 4 & $14.00 \%$ & 24 & $13.40 \%$ & 47 \\
\hline Yes, but without prior informed consent for this procedure. & $25.00 \%$ & 37 & $22.20 \%$ & 38 & $17.90 \%$ & 63 \\
\hline No & $53.40 \%$ & 79 & $46.20 \%$ & 79 & $54.30 \%$ & 191 \\
\hline I don't remember & $13.50 \%$ & 20 & $4.10 \%$ & 7 & $3.10 \%$ & 11 \\
\hline Not applicable (Elective C-section) & $5.40 \%$ & 8 & $13.50 \%$ & 23 & $11.40 \%$ & 40 \\
\hline \multicolumn{7}{|c|}{$\chi^{2}(2)=42.751 ; p<0.001$} \\
\hline
\end{tabular}

Table 4: Feelings experienced by respondents during childbirth.

\begin{tabular}{|c|c|c|c|c|c|c|}
\hline \multicolumn{7}{|c|}{ What are your memories of your childbirth? } \\
\hline & \multicolumn{2}{|c|}{$\begin{array}{l}\text { Group } 1 \\
N=148\end{array}$} & \multicolumn{2}{|c|}{$\begin{array}{c}\text { Group } 2 \\
\mathrm{~N}=171\end{array}$} & \multicolumn{2}{|c|}{$\begin{array}{c}\text { Group } 3 \\
\mathrm{~N}=352\end{array}$} \\
\hline Answers & $\%$ & $\mathbf{N}$ & $\%$ & $\mathbf{N}$ & $\%$ & $\mathbf{N}$ \\
\hline Definitely positive & $14.20 \%$ & 21 & $33.30 \%$ & 57 & $32.40 \%$ & 114 \\
\hline Rather positive & $31.80 \%$ & 47 & $28.70 \%$ & 49 & $33.50 \%$ & 118 \\
\hline Neither positive nor negative & $22.30 \%$ & 33 & $14.60 \%$ & 25 & $14.50 \%$ & 51 \\
\hline Rather negative & $18.90 \%$ & 28 & $14.60 \%$ & 25 & $10.50 \%$ & 37 \\
\hline Definitely negative & $21.80 \%$ & 19 & $8.80 \%$ & 15 & $9.10 \%$ & 32 \\
\hline \multicolumn{7}{|c|}{$\chi 2(2)=26.476 ; p=0.001$} \\
\hline \multicolumn{7}{|c|}{ Were you satisfied with the perinatal care received? } \\
\hline & \multicolumn{2}{|c|}{$\begin{array}{c}\text { Group } 1 \\
N=148\end{array}$} & \multicolumn{2}{|c|}{$\begin{array}{c}\text { Group } 2 \\
\mathrm{~N}=171\end{array}$} & \multicolumn{2}{|c|}{$\begin{array}{c}\text { Group } 3 \\
\mathrm{~N}=352\end{array}$} \\
\hline Answers & $\%$ & $\mathbf{N}$ & $\%$ & $\mathbf{N}$ & $\%$ & $\mathbf{N}$ \\
\hline Definitely yes & $16.20 \%$ & 24 & $37.40 \%$ & 64 & $50.60 \%$ & 178 \\
\hline Rather yes & $35.10 \%$ & 52 & $32.20 \%$ & 55 & $33.20 \%$ & 117 \\
\hline It's hard to say & $20.90 \%$ & 31 & $13.50 \%$ & 23 & $3.40 \%$ & 12 \\
\hline
\end{tabular}




\begin{tabular}{|c|c|c|c|c|c|c|}
\hline Rather not & $16.90 \%$ & 25 & $9.40 \%$ & 16 & $6.80 \%$ & 24 \\
\hline Definitely not & $10.80 \%$ & 16 & $7.60 \%$ & 13 & $6.00 \%$ & 21 \\
\hline \multicolumn{2}{|c|}{$\chi^{2}(2)=81.369 ; \mathrm{p}<0.001$} \\
\hline
\end{tabular}

Table 5: Place and method of delivery.

\begin{tabular}{|c|c|c|c|c|c|c|}
\hline \multicolumn{7}{|c|}{ What delivery method was used during your childbirth? } \\
\hline & \multicolumn{2}{|c|}{$\begin{array}{l}\text { Group } 1 \\
N=148\end{array}$} & \multicolumn{2}{|c|}{$\begin{array}{c}\text { Group } 2 \\
N=171\end{array}$} & \multicolumn{2}{|c|}{$\begin{array}{c}\text { Group } 3 \\
\mathrm{~N}=352\end{array}$} \\
\hline Answers & $\%$ & $\mathbf{N}$ & $\%$ & $\mathbf{N}$ & $\%$ & $\mathbf{N}$ \\
\hline Natural birth & $25.70 \%$ & 38 & $16.40 \%$ & 28 & $18.50 \%$ & 65 \\
\hline Vaginal delivery & $62.80 \%$ & 93 & $53.20 \%$ & 91 & $47.40 \%$ & 167 \\
\hline Operative delivery & $2.00 \%$ & 3 & $3.50 \%$ & 6 & $2.80 \%$ & 10 \\
\hline Emergency C-section & $4.70 \%$ & 7 & $14.60 \%$ & 25 & $21.60 \%$ & 76 \\
\hline Elective C-section & $4.70 \%$ & 7 & $12.30 \%$ & 21 & $9.70 \%$ & 34 \\
\hline \multicolumn{7}{|c|}{$\chi^{2}(2)=33.062 ; p<0.001$} \\
\hline \multicolumn{7}{|c|}{ Where did your childbirth take place? } \\
\hline & \multicolumn{2}{|c|}{$\begin{array}{c}\text { Group } 1 \\
N=148\end{array}$} & \multicolumn{2}{|c|}{$\begin{array}{c}\text { Group } 2 \\
N=171\end{array}$} & \multicolumn{2}{|c|}{$\begin{array}{c}\text { Group } 3 \\
\mathrm{~N}=352\end{array}$} \\
\hline Answers & $\%$ & $\mathbf{N}$ & $\%$ & $\mathbf{N}$ & $\%$ & $\mathbf{N}$ \\
\hline Public hospital & $90.50 \%$ & 134 & $93 \%$ & 159 & $92 \%$ & 325 \\
\hline Private hospital & $0.00 \%$ & 0 & $4.70 \%$ & 8 & $2.30 \%$ & 8 \\
\hline Childbirth house & $0.00 \%$ & 0 & $0.00 \%$ & 0 & $2.00 \%$ & 7 \\
\hline Labor ward & $2.70 \%$ & 4 & $0.60 \%$ & 1 & $0.00 \%$ & 0 \\
\hline Home & $6.80 \%$ & 10 & $1.80 \%$ & 3 & $3.40 \%$ & 12 \\
\hline \multicolumn{7}{|c|}{$\chi^{2}(2)=29.541 ; p<0.001$} \\
\hline
\end{tabular}

\section{Discussion}

Over $90 \%$ of all births analyzed took place in hospitals. In recent years, the number of deliveries in birth houses and at home has slightly increased. However, most women still decide to give birth in hospitals, which is confirmed by studies on the choice of place of childbirth [1]. One of the determinants of childbirth medicalization is the number of $\mathrm{C}$-sections. An increase can be noticed in the percentage of $\mathrm{C}$ - sections from less than $10 \%$ in the last century to $31 \%$ in recent years. According to the Health at a Glance 2015 report, every third child born in Poland is delivered via $\mathrm{C}$-section [2]. The growing $\mathrm{C}$-section rate can also be observed worldwide. The analysis of 121 countries showed that between 1990-2014, the global average rate increased by $12.4 \%$ [3]. In 1985 the World Health Organization (WHO) recommended that the percentage of $\mathrm{C}$-sections in any region should not exceed 10 $15 \%$ [4]. In 1985, WHO recommended that in any geographical region, the percentage of induced births should not exceed 10\% [4]. Unfortunately, based on the WHO report published 25 years later, it was found that over $25 \%$ of full-term pregnancies ended up with induction [5]. Today, every fifth woman is undergoes this procedure. For women having natural childbirth, this percentage amounts to $30-40 \%$ [6]. In the first group, more than $32 \%$ of respondents were administered uterotonics, and in less than $27 \%$ of subjects, amniotomy was performed. In turn, almost half of women (49\%) giving birth between the years 2001-2012 were given uterotonics during labor. In addition, over $36 \%$ of them had an amniocentesis. In another group, the percentage of women receiving uterotonics increased up to $54 \%$, and the percentage of amniotomies slightly decreased (31\%).

According to the WHO report issued in the 1990s there are no indications for perineal shaving or enema administration before labor [4]. Enema administration affects neither the duration of labor nor the reduction of the risk of perineal wound infection [7-9]. Despite this, in the study the percentage of women that received enema was around $65 \%$ in group 1, over 33\% in group 2 , and over $26 \%$ in group 3 . The need to remove pubic hair before childbirth was based on an assumption that this procedure reduced the risk of infection and facilitates perineal healing. According to WHO, this routine procedure may increase the risk of hepatitis and HIV infection [10]. Despite that, study results show that perineal shaving was performed in over $70 \%$ of women in group 1 , less than $34 \%$ in group 2 , and about $20 \%$ in group 3.

Women giving birth up to the late 1940s were not limited in terms of drinking or eating during labor. However, everything changed after publishing a study by an American obstetrician 
Curtis Mendelson. He assumed that pneumonia, which occurs after general anesthesia, was caused by the pulmonary aspiration of gastric contents. Thus, he recommended that women should neither eat nor drink during childbirth to decrease volume of gastric contents, thereby reducing the risk of pulmonary aspiration [11]. This recommendation reflected in our research. Specifically, in the first group of respondents, less than $10 \%$ could drink during childbirth. In 1996 WHO issued a recommendation that in the case of low-risk labor, women should be allowed to consume meals during childbirth [10]. Study results show that only $40.9 \%$ of women giving birth between 2001-2012 were allowed to drink during labor. In 2012 the Perinatal Care Standards allow women to drink clear liquids. After 2012 64.8\% of women during labor were allowed to consume liquids.

Non-pharmacological methods for childbirth pain relief include: massage, touch, change of position with the use of instruments such as a birth ball, transcutaneous electrical nerve stimulation (TENS) or water immersion. The use of non-pharmacological methods for labor pain relief may also contribute to the reduction of medical interventions during childbirth $[12,13]$. The Polish Perinatal Care Standards recommend that care providers should inform women in labor about the possibilities of nonpharmacological methods for pain relief. This study shows that only $5.4 \%$ in the first group were allowed to use nonpharmacological methods of pain relief. This situation improved in the subsequent years, because more than half of studied women (62\%) giving birth between 2001-2012, and $72 \%$ after 2012, were able to use these methods. Currently, pharmacological anesthesia during childbirth is very popular. The Polish childbirth standards allow the use of labor anesthesia. Since July 1, 2015, anesthesia during labor in Poland is available and financed by the National Health Fund (NFZ). Based on this research, only $5 \%$ of women who gave birth before 2000 were able to benefit from anesthesia. For women giving birth between 2001-2012, the percentage was 38\%, and after 2012, it was $49 \%$. Both WHO and the Polish Perinatal Care Standards emphasize that women in labor should be allowed to take comfortable positions $[4,14]$. Nevertheless, in the first group women were gave birth in a horizontal position in all Polish hospitals. Specifically, only $11 \%$ of who delivered before the year 2000 were able to take a comfortable position. Women should be encouraged to move and choose the best position for them $[15,16]$. Our results show that less than half of respondents (46\%) who gave birth between 2001-2012 could decide about the position, and 59\% after 2012 .

In 1990s, WHO clearly stated that there was no rationale behind routine episiotomy [4]. Also, the Perinatal Care Standards and the recommendations of the Polish Gynecological Society claim that episiotomy should not be performed unless there are clear medical indications [14,17]. The analysis of over 350 publications, conducted between 1960-1980, failed to confirm that episiotomy protected against complications like fetal head injury, III and IV-degree perineal tears or damage to the pelvic floor muscles [18]. Despite this, as high as $63.4 \%$ of women in group 1 had an episiotomy. The number of perineal incisions was reported to have decreased over the years, which may have been due to the acceptance of discussed recommendations by the medical staff. Poland is still one of the few countries where episiotomy is a recognized and important element of hospital births. In this study groups, a large percentage of women had episiotomy performed: group 2-57.3\%, group 3-40\%.

The possibility of having a birth partner has been guaranteed by WHO since 1985. However, in the late 1980s and the early 1990s, delivery rooms in most Polish hospitals were closed to any relatives. The first childbirth accompanied by a birth partner took place in 1983, in Łódź. Nonetheless, it was rare that a birth partner could be present. In the group of women giving birth before 2000, less than $11 \%$ could have a birth partner. This low percentage may have resulted from the fact that almost half of respondents (49\%) had to give birth in shared rooms. $62 \%$ of respondents who were in labor between 2001-2012 had the opportunity to be accompanied by their partner. The current Perinatal Care Standards also emphasize that every woman in labor should be allowed to have a birth partner. $72 \%$ of women who gave birth after 2012 were allowed to have a birth partner.

The past childbirth conditions were much different when compared to those observed nowadays. Before 2000 conditions were worse than those available today. Interestingly, although the conditions and guidelines differed between the groups, most women from all groups were satisfied with their childbirth experiences.

\section{Conclusion}

A. Childbirth conditions in the past and the present are significantly different. Changes reported in the last few decades have improved the comfort of childbirth. However, the development of obstetrics has also contributed to a higher number of medical procedures, and hence greater medicalization of childbirth.

B. Most studied women had positive childbirth memories despite the differences in both conditions and time. Therefore, it can be concluded that appropriate care oriented toward individual needs can compensate for any inconveniences related to facilities or equipment.

\section{References}

1. Snowden JM, Tilden EL, Snyder J, Quigley B, Caughey AB, et al. (2015) Planned out-of-hospital birth and birth outcomes. The New England Journal of Medicine 373(27): 2642-2653.

2. OECD (2015) Health at a glance 2015: OECD Indicators, OECD Publishing, Paris.

3. Betrán AP, Ye J, Moller AB, Zhang J, Gülmezoglu AM, et al. (2016) The increasing trend in caesarean section rates: Global, regional and national estimates: 1990-2014. PloS One 11(2): e0148343.

4. (1985) Appropriate technology for birth. Lancet 326(8452): 436-437.

5. WHO (2011) WHO recommendations for induction of labour. WHO, Europe. 
6. Nicholson JM, Kellar LC, Henning GF, Waheed A, Gonzalez MC, et al (2015) The association between the regular use of preventive labour induction and improved term birth outcomes: Findings of a systematic review and meta-analysis. An International Journal of Obstetrics and Gynaecology 122(6): 773-784.

7. Basevi V, Lavender T (2014) Routine perineal shaving on admission in labour. Cochrane Database of Systematic Reviews, pp. 1-24.

8. Drayton S, Rees C (1984) They know what they're doing. Do nurses know why they give pregnant women enemas? Nurs Mirror 159(5): 4-8.

9. Romney ML, Gordon H (1981) Is your enema really necessary? Br Med J (Clin Res Ed) 282(6272): 1269-1271.

10. (1997) Care in normal birth: A practical guide. Technical working group, World Health Organization. Birth 24(2): 121-123.

11. Mendelson CL (1946) The aspiration of stomach contents into the lungs during obstetric anesthesia. American Journal of Obstetrics and Gynecology 52(2): 191-205.

12. Cochrane A (2015) Perceptions of labor and delivery clinicians on non pharmacological methods for pain relief during labor. Senior Honors Theses.
13. Jones LV (2015) Non-pharmacological approaches for pain relief during labour can improve maternal satisfaction with childbirth and reduce obstetric interventions. Evidence Based Nursing 18(3): 70.

14. Regulation of the Ministry of Health (2012) On the standards of conduct and medical procedures when providing perinatal care over women during physiological pregnancy, physiological labor, puerperium, and neonatal care. Journal of Laws.

15. Gizzo S, Gangi SD, Noventa M, Bacile V, Zambon A, et al. (2014) Women's choice of positions during labour: Return to the past or a modern way to give birth? a cohort study in Italy. Biomed Research International 2014: 1-7.

16. Guittier MJ, Girard VO, de Gasquet B, Irion O, Boulvain M (2016) Maternal positioning to correct occiput posterior fetal position during the first stage of labour: A randomised controlled trial. An International Journal of Obstetrics and Gynaecology 123(13): 2199-2207.

17. Spaczyński M (2005) Recommendations of the Polish Society of Obstetrics and Gynecology for prenatal care in normal pregnancy. Ginekol Pol 76(7): 517-527.

18. Thacker SB, Banta HD (1983) Benefits and risks of episiotomy: An interpretative review of the English language literature, 1860-1980. Obstetrical \& Gynecological Survey 38(6): 322-338. 